\title{
MED/ARB: FRAUGHT WITH DANGER OR RIPE WITH OPPORTUNITY?
}

\author{
DAVID C. ELLIOTT ${ }^{*}$
}

Parties in dispute, or contemplating a dispute resolution process, want to settle their disputes amicably, but equally want the dispute resolved. Lawyers must assess what, at first sight, might seem poor choices for dispute resolution. This article examines an increasingly popular process - using a combined mediation/arbitration process to settle disputes - med/arb.
Les parties à un différend, ou envisageant d'adopter un processus de résolution des différends, souhaitent $\dot{a}$ fois un arrangement $\dot{a}$ l'amiable et le règlement de leur conflit. Les membres du barreau doivent d'abord considérer ce qui constitue des solutions médiocres à cet égard. Le présent article examine un processus de plus en plus populaire qui allie médiation et arbitrage : med/arb.

\section{TABLE OF CONTENTS}

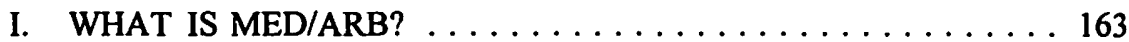

II. THE ATTRACTIONS OF MED/ARB $\ldots \ldots \ldots \ldots \ldots \ldots \ldots 164$

III. HIGH PROFILE MED/ARB SUCCESSES $\ldots \ldots \ldots \ldots \ldots \ldots 165$

IV. THE QUANDRY OF MED/ARB $\ldots \ldots \ldots \ldots \ldots \ldots \ldots \ldots$

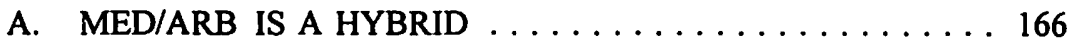

B. NATURAL JUSTICE CONCERNS $\ldots \ldots \ldots \ldots \ldots \ldots 166$

C. LACK OF CONTROL . . . . . . . . . . . . . . 167

V. LEGISLATIVE AND INSTITUTIONAL TRENDS $\ldots \ldots \ldots \ldots 168$

VI. MORE THOUGHT ABOUT

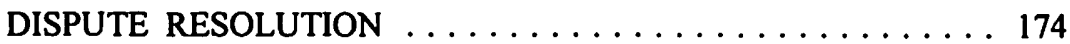

VII. DESIGNING A MED/ARB PROCESS $\ldots \ldots \ldots \ldots \ldots \ldots 175$

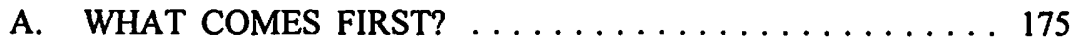

B. THE ROLE OF THE IMPARTIAL

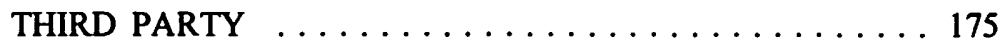

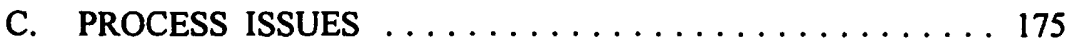

D. THE MEDIATOR/ARBITRATOR $\ldots \ldots \ldots \ldots \ldots \ldots 176$

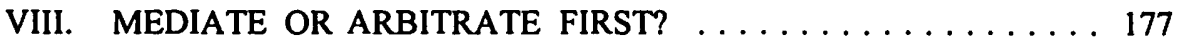

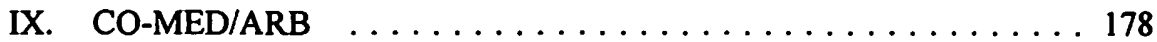

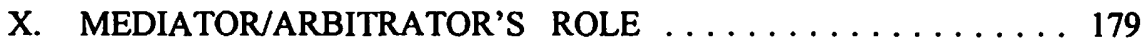

XI. CONCLUSION .................... 179

\section{WHAT IS MED/ARB?}

Med/arb is a process by which both mediation and arbitration are agreed upon as the means by which parties intend to resolve their dispute. Typically, although by no means always, one person is appointed both to mediate and, if mediation fails, to arbitrate the dispute.

Barrister and Solicitor, Alberta. Solicitor of the Supreme Court of Judicature, England (nonpractising), Barrister, New Zealand (non-practising), Chartered Arbitrator and practising mediator. Elliott has been appointed as mediator/arbitrator on several occasions. Each dispute has settled in mediation. He has been a labour arbitrator for 14 years with experience in final offer selection arbitration. 
An increasing number of variations on the med/arb process are emerging: mediate first and if mediation fails, arbitrate; start arbitration proceedings and allow for mediation at some point during the arbitration; mediate some issues and arbitrate others; mediate, then arbitrate some unresolved issues, then return to mediation; mediate, if unsuccessful ask for an "advisory opinion" by the mediator which is binding as an award unless either party vetoes the opinion within a limited period of time. Another med/arb variation ${ }^{1}$ growing in popularity is mediation, if unsuccessful, followed by a final offer by each side, coupled with limited argument, following which the mediator turned arbitrator must choose one or other of the offers.

\section{THE ATTRACTIONS OF MED/ARB}

Most people, at least in the early stages of a dispute, do not want to engage in a time-consuming, costly and often frustrating adversarial arbitration or litigation process. The med/arb concept is attractive primarily because:

- mediation offers another chance of working out the dispute while retaining control of the decision and "getting on with business";

- the arbitration ${ }^{2}$ component is attractive because, if mediation does not resolve the dispute, arbitration provides a clear end point, usually within a reasonably acceptable time frame, within a process that can be designed by the parties in dispute, and with a decision maker of the disputants' choice;

- if the mediator is trusted, the parties often feel that he or she is in as good a position as anyone to make a decision on the dispute in the arbitration phase of the process;

- the time spent in mediation, with the mediator, serves as a means of giving the mediator enough information for a decision to be made, so time is not "wasted" in a subsequent arbitration hearing; ${ }^{3}$

- the process is relatively informal, the result comparatively speedy, and the costs controllable.

Some community mediation centre administrators in the United States see med/arb as simply a more effective dispute settlement technique. From their perspective, a mediator/arbitrator has "decision-making authority" as an extra tool to help parties overcome bargaining obstructions like posturing, overreaching and overreaction.

More variations of the process are mentioned later in this article.

Alberta's modern Arbitration Act, S.A. 1991, c. A-43.1, one of a new generation of Canadian arbitration Acts, provides an opportunity for the parties to design the arbitration process to meet their needs.

3 Whether or not the information in a mediation is appropriate and sufficient for decision-making is a moot point - but the parties in dispute often think it is. 
Presumably some of this thinking has gone into mediation/arbitration legislation passed to settle some of Canada's labour relations disputes.

As McLaren and Sanderson put it:

Linking the two techniques together creates an ADR dynamic that makes the whole a more effective force than the sum of the two components used individually. ${ }^{4}$

The ability to design a med/arb process to suit the specific needs of parties in a dispute is particularly attractive to many disputants. All the flexibility possible in mediation and all the flexibility available within an arbitration process is also available in a med/arb process.

\section{HIGH PROFILE MED/ARB SUCCESSES}

One reason med/arb is being used more in Canada is the success it has achieved in several high profile cases in the United States. These success stories are well documented elsewhere, ${ }^{5}$ but three success stories illustrate the point:

- IBM and Fujitsu became embroiled in a high profile multi-million dollar dispute. The issues were ultimately resolved by a combined med/arb process. A key component of this success was the way in which the arbitrators took hold of the process and refused to allow the parties or themselves to be caught up in adversarial proceedings. Negotiation, mediation and limited arbitration proceedings resolved the dispute.

- Conoco Inc. and Browning Ferris Industries became involved in an environmental clean-up dispute over responsibility for paying to cleanup a holding pond in which hazardous chemicals had been dumped. After 3 years of fruitless litigation and ever increasing cost and complexity, the parties agreed to med/arb. Nine months of mediation settled most issues and narrowed the difference between the parties over liability. The mediator became arbitrator and chose one of the final offers made by each party after about one hour of legal argument.

- Federal Deposit Insurance Corporation and Chery, Bekart and Holland involved a claim that auditors had misrepresented the status of a bank which had defaulted. After spending $\$ 2$ million in fees and costs without getting to trial, the parties agreed to mediation, and ultimately to final offer arbitration to settle the remaining issues. 


\section{THE QUANDRY OF MED/ARB}

The thought of mixing mediation and arbitration, with one person playing the role of both mediator and arbitrator, sends shudders through many lawyers. Why?

\section{A. MED/ARB IS A HYBRID}

Mediation and arbitration are such distinctly different processes, often aimed at achieving very different results, that the thought of trying to combine them is an anathema to many. The basic differences include the following:

- in mediation, the mediator will seek to surface the interests of the parties in dispute with a view to broadening the potential options for settlement. In arbitration, the last thing either party may want to expose is their underlying interests;

- in mediation, the mediator controls the process and often much of the questioning. In arbitration, the arbitrator is typically less involved in questioning, allowing the parties or their counsel to present their case. This lack of process control troubles many lawyers;

- in mediation, the parties may each privately caucus with the mediator. In most arbitrations, this would result in the decision being overturned;

- in mediation, the parties will attempt to make a settlement seeking to meet their own and the other parties' interests. This will typically involve fashioning an agreement looking to their future relationship. In arbitration, interests are submerged by rights, with each side tending to cast their own case in the best light, and their opponents' in the worst;

- there is not one mediation process but many. Which process is used will largely depend on the background and training of the mediator. Some of those with a strong labour relations background may tend to be more directive and assertive in mediation sessions than those schooled in the Harvard model of principled negotiation, or in western Canada, in the teachings of the British Columbia Justice Institute or the Alberta Arbitration and Mediation Society.

\section{B. NATURAL JUSTICE CONCERNS}

What causes lawyers most concern is a mediator privately caucusing with each side. Fundamental to our notion of justice is the right to know and be able to answer an opponents' case. How can this be done if one side or the other has no way of knowing what the other party is saying? It is unsettling to think of what the other side might have said, and what influence that might have on the mediator turned arbitrator.

While private caucus meetings are problematic for lawyers, they can also pose a dilemma for the mediator-turned-arbitrator. How much reliance, if any, can be placed 
on what is said in caucus meetings (when some very frank comments might be made and when the other side may have no opportunity to rebut what is said, or to shed other light on them, or put them in a different context)?

A med/arb process may raise questions of bias, real or perceived, in the minds of the parties. This issue is most likely to arise if the mediator is particularly assertive, or provides an advisory opinion in the course of the mediation (an "advisory opinion" is a non-binding expression of the mediator's opinion of the most likely outcome if the case goes to arbitration, based on what the mediator has heard in mediation). Equally, as a result of private caucus sessions, the mediator may feel biased to one side or other on the basis of what he or she hears in confidence.

Natural justice concerns are most often raised in jurisdictions with a mediation process that relies heavily on private caucusing and looks to the mediator providing formal or informal advice or opinions on the relative positions of the parties. The more progressive approach to mediation relies far less on private caucusing and far more on skills designed to keep the parties at the table and looking at different approaches to tackling the dispute. This is not to say that private caucusing does not or should not occur (with its attendant natural justice concerns) but it is less prevalent than it once was.

"Natural justice" concerns can be dealt with satisfactorily in a med/arb process, but only if they are canvassed, considered and dealt with by the parties on a fully informed basis.

\section{LACK OF CONTROL}

A client who speaks out of turn in court will soon find who is allowed to speak and when. The judge and counsel control the process and, for the most part, the conduct of their clients. Much the same applies in arbitration proceedings. In mediation, quite the reverse is true. Not only can clients speak freely, but they will be invited to do so, and people will listen! This freedom can be unnerving for some counsel confident in their control of the process and of rules of court to deal with any eventuality.

Of additional concern to some, the mediator has a direct effect on the mediation process. The questions asked by the mediator will seek to bring out the interests of the parties in order to expand the settlement possibilities. The very issues that can play a vital role in mediation may be precisely the things counsel may not want canvassed in an arbitration hearing. Once underlying interests have surfaced during a mediation, it may be unrealistic to expect a mediator-turned-arbitrator to put them aside when making an arbitration award. In fact, to put aside what is said in mediation may well lessen the quality of the decision, even if it is theoretically and practically possible to do so.

Also, the quality of the information provided during mediation may be a concern. Information is not given under oath, although with all parties present this is unlikely to be a significant practical problem. What may be of more concern is the attention the 
mediator pays to the information traded by the parties. In mediation, it is much less important that the mediator understands the issues than that the parties understand what the other is saying and why. If communication is going well, the mediator will not interrupt, even though he or she may not fully understand the content or its importance. On the other hand, in arbitration, the parties present their cases with a view to persuading the arbitrator to their view and will make sure the arbitrator understands the issues. And the arbitrator will certainly make sure he or she understands the issues before adjourning to make a decision.

None of these concerns are intended to suggest that the legal profession as a whole opposes med/arb. In fact, it is lawyers who have pioneered the med/arb process and, in many respects, recent innovative judicial experimentations incorporate med/arb concepts.

The rest of this article looks at legislative and institutional trends, and considers how these two very different approaches to conflict resolution - mediation and arbitration - can, with careful management, be successfully combined.

\section{LEGISLATIVE AND INSTITUTIONAL TRENDS}

In its 1988 Proposals for a New Alberta Arbitration Act, ${ }^{6}$ the Institute of Law Research and Reform ${ }^{7}$ proposed the following section:

For the purpose of encouraging settlement of a dispute, an arbitral tribunal may, with the agreement of the parties, employ mediation, conciliation or other procedures at any time during the arbitration proceedings and, with the agreement of the parties, the members of the arbitration tribunal are not disqualified from resuming their role as arbitrators by reason of the mediation, conciliation or other procedure. $^{8}$

The Institute's proposal to permit an arbitral tribunal to use mediation or other alternative procedures during arbitration proceedings was not made without reservations. Commented the Institute:

It is obvious that having an arbitrator change his role to that of mediator and back to arbitrator again, ... is fraught with danger. ${ }^{9}$

The Institute's proposals for reform were, in a slightly modified form, adopted by the Alberta Legislature in Alberta's new Arbitration Act. Section 35 of the Act reads: ${ }^{10}$

Report No. 51, October 1988 [Report No. 51].

Now the Alberta Law Reform Institute.

Report No. 5I, supra note 6 at 98.

Ibid.

Following the Institute's report, the Canadian Uniform Law Conference considered the subject of arbitration and made its own proposals (based largely on the Institute's work) for a Uniform Arbitration Act (Uniform Law Conference of Canada, "Proposals for a Uniform Arbitration Act" (Proceedings of the 72 nd Annual Meeting, August 1990) at 86.) which was enacted with minor modifications by Alberta in 1991 as the Arbitration Act, supra note 2. 
35(1) The members of an arbitral tribunal may, if the parties consent, use mediation, conciliation or similar techniques during the arbitration to encourage settlement of the matters in dispute.

(2) After the members of an arbitral tribunal use a technique referred to in subsection (1), they may resume their roles as arbitrators without disqualification.

In recent time, the debate over a mediator becoming arbitrator has pitted "natural justice" concerns (which tend to oppose mixing mediation and arbitration processes) against "party autonomy" concepts - the notion that parties to a dispute should be free to make whatever agreement they want, including med/arb, to resolve their dispute. Increasingly, although certainly not universally, the party autonomy view seems to be gaining the upper hand."

Concern over natural justice issues is reflected in legislative provisions; in particular, that arbitrators are not disqualified from resuming their role as arbitrator "by reason only" of the arbitrators' participation in mediation, conciliation, or similar techniques. It may well be that a court would find a private caucus by an arbitrator-turned-mediator with one or other of the parties is not what the legislature intended to permit. ${ }^{12}$ On the other hand, a court may find that well-informed parties are free to agree on private caucusing and cannot later complain if the result does not turn out to their satisfaction. Although the latter is the better view (if the parties are well informed), this debate is not over, ${ }^{13}$ except in those jurisdictions that have dealt with the issue directly. New South Wales, for example, specifically allows parties to contract out of natural justice rules when an arbitrator turns to the mediation phase of the process. ${ }^{14}$

Alberta, in common with other Canadian jurisdictions, has passed the International Commercial Arbitration Act. ${ }^{15}$ Section 5 of that Act is in the same form as that

" For United Kingdom editorial comment and debate on the subject, see A.W. Shilston, "Med-Arb - Can it Work?" (1994) 60:1 J.C.I. Arb. 1; P. Newman, "Mediation-Arbitrator (Med-Arb) Can it Work Legally?" (1994) 60:3 J.C.I. 173; A.W. Shilston, "The Med-Arb Debate Continued" (1994) 61:2 J.C.1. Arb. 111.

12 Despite the freedom to waive or modify most of the provisions of the Alberta Arbitration Act, some sections cannot be modified. One of these is s. 19, which reads:

19(1) An arbitral tribunal shall treat the parties equally and fairly.

(2) Each party shall be given an opportunity to present a case and to respond to the other parties' cases.

The effect of this provision is that any mediation conducted in the course of arbitration proceedings under the Alberta Arbitration Act must meet the requirements of s. 19. Whether this bars private caucusing is debatable. Of course, if mediation is undertaken before arbitration starts, or the process is not conducted under the $A c t$, the concern is lessened, although not necessarily removed.

13 A.W. Shilston, Honourary Editor of Arbitration, the United Kingdom Journal of the Chartered Institute of Arbitrators, continues to wage a valiant battle to shift arbitration out of archaic adversarial legalistic processes, so far, with apparently limited success, judging by his comments in "The Med-Arb Debate Continued," supra note 11.

14 Commercial Arbitration (Amendment) Act 1990, N.S.W., 1990, Act. No. 100, s. 27(3).

is S.A. 1986, c. I-6.6. [The Act does two things: it applies the Convention on the Recognition and Enforcement of Foreign Arbitral Awards adopted by the United Nations Conference on International Commercial Arbitration in 1958; secondly the Convention applies the Model Law on 
recommended by the Institute of Law Research and Reform in 1988, allowing an arbitrator to use mediation and conciliation without disqualification. ${ }^{16}$

Med/arb has also been used in a variety of Canadian labour relations contexts, particularly in British Columbia. British Columbia's Labour Relations Code contemplates the appointment of a mediator/arbitrator, with the objective to first endeavour to assist the parties to settle a grievance by mediation, but if the parties are unable to do so, to then determine the grievance by arbitration. ${ }^{17}$ John Sanderson, Q.C. commented on that legislation:

It ... vividly demonstrates that designing a more imaginative and flexible dispute resolution environment is not beyond the capacity of the labour relations community.... ${ }^{18}$

International Commercial Arbitration adopted by the United Nations Commission on Intemational Trade Law in 1985 (UNCITRAL)]. Section 5 of the Act is enacted in that context. Note that $\mathbf{s} .5$ is not part of UNCITRAL. The federal government, when it adopted UNCITRAL in 1985, did not adopt a section equivalent to s. 5. (See Commercial Arbitration Act, R.S.C. 1985, (2d Supp) c. 17). For two examples of legislated med/arb processes in Canada see: British Columbia Grain Handling Operations Act, S.C. 1991, c. 25, ss. 8, 19; and Canada Elections Act, R.S.C. 1985, c. E-2, ss. 308-9, 315, 317.

Section 105 of the Labour Relations Code, R.S.B.C. 1992, c. 82 reads

Consensual mediation-arbitration

105(1) Despite any grievance or arbitration provision in a collective agreement or deemed to be included in a collective agreement under section 84(3), the parties to the collective agreement may, at any time, agree to refer one or more grievances under the collective agreement to a single mediatorarbitrator for the purpose of resolving the grievances in an expeditious and informal manner.

(2) The parties shall not refer a grievance to a mediator-arbitrator unless they have agreed on the nature of any issues in dispute.

(3) The parties may jointly request the director to appoint a mediator-arbitrator if they are unable to agree on one, and the director shall make the appointment.

(4) Subject to subsection (5), a mediator-arbitrator appointed by the director shall begin proceedings within 28 days after being appointed.

(5) The director may direct a mediator-arbitrator to begin proceedings on such date as the parties jointly request.

(6) The mediator-arbitrator shall endeavour to assist the parties to settle the grievance by mediation.

(7) If the parties are unable to settle the grievance by mediation, the mediatorarbitrator shall endeavour to assist the parties to agree on the material facts in dispute and then shall determine the grievance by arbitration.

(8) When determining the grievance by arbitration, the mediator-arbitrator may limit the nature and extent of evidence and submissions and may impose such conditions as he or she considers appropriate.

(9) The mediator-arbitrator shall give a succinct decision within 21 days after completing proceedings on the grievance submitted to arbitration.

(10) Sections 89 to 103 apply in respect of a mediator-arbitrator and a settlement, determination or decision under this section. 
Vince Ready, a leading British Columbia labour relations mediator and arbitrator, says med/arb is gaining favour in British Columbia and other parts of the country. ${ }^{19}$ Ready sees the primary advantage to med/arb as the quality of the settlement, either because it is entirely or partially resolved through the mediation part of the process, or because the award is more likely to be in line with the needs of the parties as a result of the enhanced knowledge that the mediator/arbitrator has by participating in the mediation process.

The med/arb process is also used in the labour relations context in Alberta, without supporting legislation. ${ }^{20}$

Three overseas examples show that the med/arb trend is not confined to North America. In Australia, the med/arb process has had limited legislative sanction for over a decade. In some Australian states it is now firmly and directly supported by legislation. For example, in its present form, section 27 of the Commercial Arbitration $\mathrm{Act}^{21}$ states:

27(1) Parties to an arbitration agreement:

(a) may seek settlement of a dispute between them by mediation, conciliation or similar means; or may authorize an arbitrator or umpire to act as a mediator, conciliator or other nonarbitral intermediary between them...

whether before or after proceeding to arbitration, and whether or not continuing with the arbitration.

(2) Where:

an arbitrator or umpire acts as a mediator, conciliator or intermediary ... and

that action fails to produce a settlement of the dispute acceptable to the parties to the dispute, Conference, Calgary, 1993) at 22 [unpublished]. involved in med/arb processes. For other comment on med/arb in a labour relations context, see the paper presented to the National Academy of Arbitrators by Professor Daniel Ish, June 1993, titled "Alternative and Hybrid Processes for Resolving Disputes" (reproduced in G. Grueberg, ed., World of Work: Proceedings of the Forty-Sixth Annual Meeting of the National Academy of Arbitrators (Washington, D.C.: The Bureau of "National" Inc., 1994) at 96. 
no objection shall be taken to the conduct by the arbitrator or umpire of the subsequent arbitration proceedings solely on the ground that the arbitrator or umpire had previously taken that action in relation to the dispute.

(3) Unless the parties otherwise agree in writing, an arbitrator is bound by the rules of natural justice when seeking a settlement under subsection (1).

This section was designed to resolve questions under the former section which permitted settlement conferences (and other techniques) in the course of arbitration proceedings without disqualifying the arbitrator. Controversy over whether "natural justice rules" applied during settlement conferences and other settlement attempts, led to the new section which gives the parties the ability to contract in to mediation and other settlement processes, and to contract out of natural justice rules, if they wish.

Singapore's 1994 International Arbitration Act includes these sections: ${ }^{22}$

Appointment of conciliator

16(3) Where an arbitration agreement provides for the appointment of a conciliator and further provides that the person so appointed shall act as an arbitrator in the event of the conciliation proceedings failing to produce a settlement acceptable to the parties

(a) no objection shall be taken to the appointment of such person as an arbitrator, or to his conduct of the arbitral proceedings, solely on the ground that he had acted previously as a conciliator in connection with some or all of the matters referred to arbitration;

(b) if such person declines to act as an arbitrator, any other person appointed as an arbitrator shall not be required first to act as a conciliator unless a contrary intention appears in the arbitration agreement.

Power of arbitrator to act as conciliator

17(1) If all parties to any arbitral proceedings consent in writing and for so long as no party has withdrawn his consent in writing, an arbitrator or umpire may act as a conciliator.

(2) An arbitrator or umpire acting as conciliator-

(a) may communicate with the parties to the arbitral proceedings collectively or separately; and

(b) shall treat information obtained by him from a party to the arbitral proceedings as confidential, unless that party otherwise agrees or unless subsection (3) applies. 
(3) Where confidential information is obtained by an arbitrator or umpire from a party to the arbitral proceedings during conciliation proceedings and those proceedings terminate without the parties reaching agreement in settlement of their dispute, the arbitrator or umpire shall before resuming the arbitral proceedings disclose to all other parties to the arbitral proceedings as much of that information as he considers material to the arbitral proceedings.

(4) No objection shall be taken to the conduct of arbitral proceedings by a person solely on the ground that that person had acted previously as a conciliator in accordance with this section.

Leading arbitration institutions throughout the world are including provisions for med/arb in their rules. The rules can be adopted by parties in dispute as the means by which their dispute is to be resolved. Two examples will suffice.

The Rules for International Commercial Arbitration and Conciliation Proceedings of the British Columbia International Commercial Arbitration Centre contemplate a conciliator subsequently acting as the arbitrator of the same dispute. Rule 11(5) says:

11(5) Where an arbitration agreement provides

(a) for the appointment of a conciliator, and

(b) that the conciliator shall also act as arbitrator in the event of the conciliation proceedings failing to produce a settlement, a party shall not object to the appointment of a conciliator as arbitrator solely on the ground that he had acted as conciliator in connection with some or all of the matters referred to in the arbitration. ${ }^{23}$

\section{The World Intellectual Property Organization Rules ${ }^{24}$ say:}

(a) The mediator shall promote the settlement of the issues in dispute between the parties in any manner that the mediator believes to be appropriate, but shall have no authority to impose a settlement on the parties.

(b) Where the mediator believes that any issues in dispute between the parties are not susceptible to resolution through mediation, the mediator may propose, for the consideration of the parties, procedures or means for resolving those issues which the mediator considers are most likely, having regard to the circumstances of the dispute and any business relationship between the parties, to lead to the most efficient, least costly and most productive settlement of those issues. In particular, the mediator may so propose:

The International Commercial Arbitration Act, S.B.C. 1986, c. 14, s. 2(3) says that where the Act refers to an agreement of the parties, that agreement includes any arbitration rules referred to in the agreement. 
(i) an expert determination of one or more particular issues;

(ii) arbitration;

(iii) the submission of last offers of settlement by each party and, in the absence of a settlement through mediation, arbitration conducted on the basis of those last offers pursuant to an arbitral procedure in which the mission of the arbitral tribunal is confined to determining which of the last offers shall prevail; or

(iv) arbitration in which the mediator will, with the express consent of the parties, act as sole arbitrator, it being understood that the mediator may, in the arbitral proceedings, take into account information received during the mediation.

\title{
WIPO recommends the following clause for a med/arb process: ${ }^{25}$
}

\begin{abstract}
Any dispute, controversy or claim arising under, out of or relating to this contract and any subsequent amendments of this contract, including, without limitation, its formation, validity, binding effect, interpretation, performance, breach or termination, as well as non-contractual claims, shall be submitted to mediation in accordance with the WIPO Mediation Rules. The place of mediation shall be ... The language to be used in the mediation shall be ...
\end{abstract}

If, and to the extent that, any such dispute, controversy or claim has not been settled pursuant to the mediation within [60] [90] days of the commencement of the mediation, it shall, upon the filing of a Request for Arbitration by either party, be referred to and finally determined by arbitration in accordance with the WIPO Arbitration Rules. Alternatively, if, before the expiration of the said period of [60] [90] days, either party fails to participate or to continue to participate in the mediation, the dispute, controversy or claim shall, upon the filing of a Request for Arbitration by the other party, be referred to and finally determined by arbitration in accordance with the WIPO Arbitration Rules. The arbitral tribunal shall consist of [three arbitrators] [a sole arbitrator]. The place of arbitration shall be.... The language to be used in the arbitral proceedings shall be ... The dispute, controversy or claim referred to arbitration shall be decided in accordance with the law of ...

\section{MORE THOUGHT ABOUT DISPUTE RESOLUTION}

A great deal more thought is now going into dispute resolution clauses. The Alberta Law Reform Institute's report ${ }^{26}$ on the drafting of dispute resolution clauses means that, for the first time in Alberta, both lawyers and clients will have available a comprehensive and accessible text on what should be considered while drafting arbitration clauses. It will be a valuable resource. But more and more agreements go further, and commit parties to mediation before moving to an adversarial arbitration process which takes the decision out of their hands. Faced with a dispute under a contract that requires or suggests mediation before arbitration, clients are going to ask whether the same person can do both. The answer is a definite "perhaps." 


\section{DESIGNING A MED/ARB PROCESS}

Faced with a request to prepare a med/arb process, four series of questions need to be answered:

\section{A. WHAT COMES FIRST?}

Consider the order of the process best suited to the dispute or disputes contemplated. The process could be:

- $\quad$ mediation followed by arbitration;

- $\quad$ arbitration proceedings in which mediation is used at an appropriate point;

- mediation followed by an expedited arbitration process;

- at appropriate points, a mix of processes, alternating mediation and arbitration as the situation requires.

\section{B. THE ROLE OF THE IMPARTIAL THIRD PARTY}

A second series of questions deals with the person or persons appointed as the impartial third party:

- is one person to be appointed as both mediator and arbitrator at the outset of proceedings?

- if mediation fails, is the mediator automatically to become arbitrator or is the mediator to be subject to a time-limited confirmation or veto process? Does the mediator have a similar opportunity to decline to serve as arbitrator?

- if two persons are to be appointed, what will be their respective roles?

\section{PROCESS ISSUES}

A third series of questions deals with process details:

- is the mediation process to be limited by time? Is either party, at any time, able to terminate the mediation phase and institute or continue arbitration proceedings, and if so, how?

- is private caucusing to be allowed at all? If it is, what rules are there about the information provided during private caucusing? In particular, what is the mediator turned arbitrator to do with that information? Options include:

- the arbitrator is not to take account or rely on information received during private caucus sessions in making a decision; 
- if account is to be taken of information provided in private caucus sessions, any of it on which the arbitrator intends to rely must be disclosed to the other side, with an opportunity given to the other party to respond;

- accept that whatever the mediator hears will be used as part of his or her decision-making in arbitration. If mediation comes first, give the parties an opportunity to present their case during the arbitration phase, or at least allow the arbitrator to ask questions or call for clarification of issues that might not have been made clear during the mediation process (If mediation occurs after formal evidence has been presented at arbitration, this problem will not arise).

- have potential natural justice issues been fully canvassed and decisions made about how to deal with them? Consider if the Arbitration Act applies and its impact on the process design.

\section{THE MEDIATOR/ARBITRATOR}

A fourth series of questions concerns the mediator/arbitrator:

- does the person have adequate training and understanding of mediation processes to conduct a sound mediation proceeding?

- will the mediator conduct the kind of process the parties want - or are the parties prepared to leave that to the mediator's discretion?

- is the person someone whose judgment can be trusted if he or she has to make an arbitration decision and is he or she competent to conduct the arbitration phase of the process?

- to what code of ethics does the mediator/arbitrator subscribe? ${ }^{27}$

- is the person able to shift from the role of mediator to arbitrator (and perhaps back again) with integrity, and to pinpoint process and substantive issues for consideration both by the parties and by himself or herself personally?

Depending on the parties and the nature of the dispute or potential disputes, each of the answers to these questions may have a bearing on whether med/arb is an appropriate process to use, and if it is, the design of that process. 


\section{MEDIATE OR ARBITRATE FIRST?}

Is it best to mediate first and if that fails move to arbitration? Or is it best to conduct an arbitration proceeding and attempt mediation at an appropriate point in the arbitration proceedings?

The Arbitration Act assumes that mediation or conciliation will form part of the arbitration proceeding. It is not uncommon, in commercial arbitration, for evidence to be lead and witnesses to be cross-examined before mediation is attempted. The parties, aware of how their evidence has been presented to the arbitrator, and of the strengths and weaknesses of their case, as well as the case of their opponent, negotiate in the mediation session on an informed basis. If the parties are able to resolve some or all of the dispute, that agreement can form part of the final award. Issues that cannot be agreed upon are decided by the arbitrator.

There are drawbacks to this form of med/arb process. As described earlier, what the mediator/arbitrator hears in mediation may improperly influence the award if one has to be made. Certain techniques, such as private caucusing, could be problematic. Even though the mediator/arbitrator is not hearing evidence for the purpose of decisionmaking during the mediation session, the information of which he or she becomes aware during those sessions may prejudice or influence a subsequent decision.

Other disadvantages with arbitrating first include the time, cost and adversarial process the parties go through before looking at solutions based on their mutual interests. Opportunities for settlement may be lost because of what is said while preparing for and during an adversarial arbitration process.

In most cases it seems more appropriate to mediate before arbitrating a dispute. The reasons for this include:

- if the mediation is successful, the parties never need to get into evidence and legal argument;

- the whole process is typically very informal, with everyone concentrated on seeking solutions to the issues rather than on contract rights;

- mediation allows more freedom for the mediator to have private meetings with each party, if need be. The full range of mediation techniques can be employed without constraint;

- at the end of mediation (if it is unsuccessful), the parties can decide whether the dispute should in fact be arbitrated by the mediator. For a variety of reasons, either or both of the parties, or the mediator, may not feel it appropriate for the arbitration to proceed with the mediator acting as arbitrator, despite the apparent initial advantages of this approach; 
- the mediation can be limited to a set period of time, and failing settlement or an agreed extension of time, the arbitration process starts;

- by using mediation first, there is the least intervention by a third person in the parties' dispute, and the parties retain total control over how and whether it can be resolved;

- in mediation, relationships are rarely damaged and are often improved;

- mediation is relatively speedy and costs less than an adversarial process.

Perhaps most important, the results of a mediation can be more far-reaching (both in terms of relationships and the agreement as a whole) than anything that can be achieved by arbitration. It makes sense to explore these opportunities before the parties limit their options to arbitration.

The disadvantages to mediating first include:

- $\quad$ if mediation is unsuccessful, time might have been "wasted." In fact this is rarely the case, because most things said in the mediation have to be said through evidence - and they would not need to be given in evidence if the parties were satisfied that all the relevant facts had come out in the mediation. At the arbitration stage it should be possible to settle on an agreed statement of facts to avoid having to present evidence through witnesses;

- the mediator may learn "too much" in mediation - material that would not be permitted as evidence in an arbitration hearing - and this extra information might influence the arbitration decision. This is a risk with either option, and is inherent in using a med/arb process, but it is something to be considered.

\section{CO-MED/ARB}

The Harvard Negotiation Project has suggested a variation of the med/arb process they call co-med/arb, which addresses some of the concerns of a med/arb process.

The co-med/arb process involves two people, one to act as mediator, the other as arbitrator. The concept is that a med/arb process can be divided into parts, one of which is not confidential while the other is confidential. The two med/arb appointees are both present during the non-confidential sessions, but only the mediator is involved in the confidential sessions.

Co-med/arb seeks to preserve the efficiency gains of a mediation process with the impartiality and more objective view of an arbitration process. In the co-med/arb process, the arbitrator can render a binding or advisory opinion, depending on the parties' agreement. 
In some respects, this technique revisits an old debate on the role and function of the grievance arbitration process in labour relations disputes. Is it intended to assist the parties in resolving disputes and so strengthen their relationship, or is the arbitrator simply an impartial outsider appointed to interpret and apply the collective agreement? The latter is now the generally accepted role of an arbitrator, but persistent complaints about the effect of that role are reason to consider other approaches which might seek the benefits of the mediation process and the strengths of the arbitration process. For some cases, co-med/arb might be such a process.

\section{MEDIATOR/ARBITRATOR'S ROLE}

If the parties know that the mediator will become the arbitrator if the dispute is not resolved, it is possible that the parties will use mediation to introduce material and say things strictly with a view to influencing the arbitrator's final decision, rather than with any real intention of reaching a settlement. Of course, if one side sees this happening, they may play the same game, or call the other party on it, but the damage may already be done. This danger can be mitigated by providing for a veto on the mediator becoming arbitrator, and by appointing a mediator/arbitrator who is trusted by both sides.

And perhaps the key point in all these considerations is whether the parties can trust the mediator/arbitrator. If they do, many concerns about med/arb will fade into the background. In reality, while the dangers are there and must be considered, it is rare for the other party or the mediator/arbitrator to be taken in by unethical tactics - they inevitably backfire.

\section{CONCLUSION}

This article has shown how mediation, a process which in its purest form seeks to uncover and meet the interests of all the parties to a dispute, regardless of their strict legal rights, can be melded with an adjudicative process, one based on the assertion of the rights of parties whatever their underlying interests may be. It shows how, with careful management, one person can play the role of both mediator and arbitrator in the same dispute.

Despite the apparent contradiction and the inherent dangers in the process, more and more people are turning to a med/arb process to ask whether it can work for them, and if so how.

With the enormous surge of interest in dispute resolution in both the public and private sectors, lawyers must be prepared to advise on and initiate a broader range of conflict avoidance and dispute resolution processes, especially those which offer less adversarial, less costly and less time consuming alternatives. Effective dispute resolution depends largely on flexible, carefully designed systems to accommodate the particular needs of the parties. This element has been given little attention by the legal profession for too long. Clients are awakening to the possibilities, and lawyers must be ready to respond to the alternatives, including the dangers and the opportunities of $\mathrm{med} / \mathrm{arb}$. 